\title{
The business of mergers ${ }^{1}$
}

\author{
by David Smith ${ }^{2}$
}

There are a few things I'd like you to know about Pricewaterhouse Coopers. When Coopers \& Lybrand and Price Waterhouse merged this summer, we identified a number of priority industries for our firm. Not surprisingly, the forest industry was one of them. Our commitment to this sector is complete. We've dedicated substantial resources - both human and financial - to ensuring that we maintain our position as the leading professional services provider to forest companies across this country and around the world.

There is no doubt that the forest industry is attractive for a number of reasons. At the same time, however, it's facing a number of challenges. That is what I'd like to speak about today: the challenges that face this industry and what the industry must do to respond - in fact, what we must do to respond and succeed in the future.

What makes forest products such a major global industry? I know this may be old hat to some of you, but bear with me. I was impressed with these statistics.

Globally, annual sales in the forest industry total about $\$ 750$ billion dollars $-\$ 750$ billion with a "B." That's a huge market - a market in which the largest forest products company has sales of only $\$ 20$ billion. Only 5 or so of the top 50 international forest product companies had sales last year of more than $\$ 10$ billion - and only 17 generate $\$ 5$ billion or more. When you compare these figures to top global performers in other industry sectors, including automotive, energy and metals, they're not very impressive.

What's my point? There's room for consolidation - a lot of room. Keep that in mind, because I'll return to it in a moment.

Here's an additional reason why the forest industry is so appealing. Only a few of the largest forest products companies are truly global, but more and more of them have finally recognized the need to globalize. That means increased profitability for the companies that play their cards right.

In Canada, the forest industry is critical.

Canada is the world's largest exporter of forest products. The forest products industry is the largest contributor to Canada's trade balance. It is Canada's largest industrial employer. Directly and indirectly, the forest products industry provides jobs for one million Canadians.

We have $10 \%$ of the world's forest area, and we have the second largest commercial softwood resource after the former USSR.

We have a highly skilled labour force and a fully developed infrastructure.

And we are a leader in sustainable development.

The conclusion should be obvious: We have a lot to win or lose - in the new world economy where forest products are concerned.

\footnotetext{
${ }^{1}$ Presented to the Annual Montreal Forest Industry Conference, 24 November 1998.

${ }^{2}$ Chairman, PricewaterhouseCoopers Canada Ltd.
}

But winning won't be easy - because we're facing a lot of challenges, many of which we heard about in this morning's presentations. As some of our speakers emphasized, the industry continues to struggle with its boom and bust character, which is caused by its high fragmentation, high capital intensity and the commodity-type nature of most of its products,

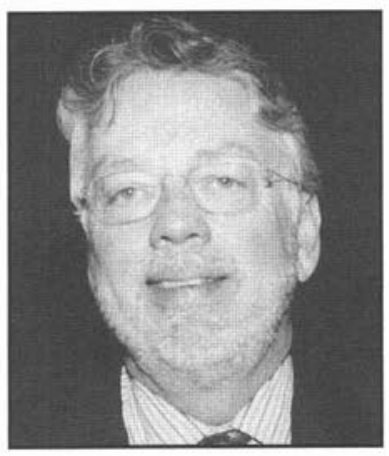
which are globally traded mostly on price.

In fact, Thomas Brodin, a European paper analyst for Salomon Smith Barney, recently commented that, "The paper industry remains one of the most fragmented industries in the world."

What is the industry doing to respond to all these challenges? What can we do to respond?

The answer was provided in a Financial Times of London article that was published a few months ago. According to that article, the mantra for the pulp and paper industry is "Consolidation, globalization, specialization."

In theory, at least, the solution for this industry is simple: consolidation, globalization, specialization. The difficulty lies in translating that theory into practice.

Let's take a quick look at these three components individually.

First, consolidation. As I mentioned earlier, the global forest industry boasts $\$ 750$ billion in annual sales, with the largest company claiming only $\$ 20$ billion of that pie. Room for consolidation? You bet.

Other statistics point to the same conclusion. In 1980, the top 10 European paper producers shared $20 \%$ of total capacity. Last year, that increased to $50 \%$. There's been a lot of progress, particulary in Europe - but there's still room for more consolidation.

By comparison, listen to this: The top four European tissue producers had $54 \%$ of the market last year. In North America the top five producers in the tissue sector have $76 \%$ of the market. Interestingly enough, the tissue market segment - the segment that boasts the highest consolidation - is one of the few pulp and paper segments that has enjoyed satisfactory returns to shareholders. Is that a coincidence? I don't think so.

Now, let's turn to globalization. Europe is setting the pattern in the forest products industry, and the pattern is this: consolidation first and globalization second. The Europeans began consolidating sooner that we did in North America, which means they're now beginning to globalize. The sooner we follow suit, the better.

Take a look at what's happening in financial markets today and you'll see that globalization is a reality. Events taking place in Asia or Russia affect our stock markets in North America almost instantly. Geographic borders simply no longer exist in today's business environment. And I'd like to take this opportunity to say that, regardless of what politicians say or do, most companies ignore political borders as well. PricewaterhouseCoopers is one of those companies. I know you can read 
between the lines. I know you understand where I'm going with this. Days before the provincial election here in Quebec, I just want you all to know that, in our opinion at least, it's business as usual. The march toward globalization continues - no matter what happens to President Clinton!

Now, back to the third part of our three-part mantra: specialization. As we'll see in a moment, the key word here is focus, focus, focus. "To win in the world market, our forest companies must put their focus on core business - manufacturing pulp, paper or wood products. Essential functions that don't add value are distractions we simply don't need.

Consolidation, globalization, specialization. It's a pretty effective mantra. In fact, I'd take it one step further and say it's a pretty universal one no matter what industry you're in.

Let me expand on the pace of global mergers and acquisitions that John Valentini and Steve Einstein spoke about this morning. In Canada, the number of transactions in 1997 increased $7 \%$, but volume increased $34 \%$ — amounting to $\$ 101$ billion in transactions.

Of the 1300 transactions that took place, 13 were worth \$1 billion or more. Two percent of the activity accounted for approximately one-third of the volume. That was thanks in part the $\$ 4.1$ billion merger of Abitibi-Price and Stone-Consolidated, which Pat Crowley told us about. That merger was the second largest of the year, just ahead of Great-West's purchase of London Insurance and just behind Seagram's sale of U.S. television assets to HSN.

Looking to the U.S., 8 of the 10 largest deals in the country's history were announced in the second quarter of this year. With $\$ 592$ billion in announced transactions, second-quarter activity more than quadrupled the deal volume announced in the same time frame last year.

There is, however, a down side — and most of you are probably already aware of it. In the third-quarter of this year, activity has slowed down in Canada, in the U.S. and around the world. In fact, this slow-down has led the Financial Times to question whether "the heydey of mergers and acquisitions may be coming to an end."

Is that true? Have mergers and acquisitions already seen their glory days?

It's a difficult question to answer, especially so soon after the downturn. But let's take a look at what's happening. In Canada, transactions announced in the third quarter of this year decreased by more than $20 \%$ over last year. However, the dollar volume of all transactions remained the same, at almost \$22 billion. Fewer transactions, maybe - but the transactions were larger: an average of \$143 million over \$127 million.

What trend do these numbers point to? Consolidation has eliminated many of the smaller players - and that, in turn, has caused the dollar value of mergers to rise.

So, while the cynics may choose to view the decrease in global mergers and acquisitions as a sign of the party coming to an end, I choose to view the increase in mega-deals as a sign of consolidation. Maybe I'm an optimist. But, at the very least, we have to wait and see what the blip means over the long term. It's much too soon to speculate.

Despite what's happening on the global scene generally, there's no doubt that consolidation, globalization and specialization is alive and well in the forest industry.

Within the last few years in Canada alone we've witnessed Kruger's acquisition of Scott; Domtar's and Cascade's pack- aging joint venture; the reshaping of Repap; Bowater/Avenor; U.S. acquisitions for Alliance, St. Laurent Paperboard and Donohue; and, of course, Abitibi-Price and Stone Consolidated.

More recently on the international scene we've heard about the mergers of Sweden's Stora and Finland's Enso, announced in July; the merger of Smurfit/Stone, which has just been approved; and, in 1996, the merger of UPM and Kymmene.

What do these three mergers have in common? You guessed it: consolidation, globalization, specialization. Let's take a look at how that mantra is playing out in each of these mergers.

Stora-Enso, a merger valued at approximately $\$ 13$ billion, has already indicated that product focus will be key to their merger, reflecting the trend to specialization. The company has planned to focus on three core competencies and divest all assets associated with non-core products.

They will also focus on global growth. Stora's chairman has already been quoted as saying that the merger will create "a global player in an increasingly competitive industry."

As for the consolidation itself, the benefits are obvious. The new group estimates potential annual savings of $\$ 400$ million - $30 \%$ from streamlined production, such as longer runs and improved use of existing capacities; $20 \%$ from combining purchasing and logistics activities; $20 \%$ from combining administration costs; and $30 \%$ from tighter controls on capital spending and sharing best practices.

Smurfit-Stone, a merger valued at $\$ 7$ billion, will create the world's largest manufacturer of containerboard. It'll be a leader in North America, Latin America and Europe, with an estimated $11 \%$ share of global containerboard sales and an enhanced geographic presence on three continents. Does the organization believe in globalization? You tell me.

And, as far as specialization is concerned, they've begun narrowing their product focus and divesting non-core businesses.

Finally, consolidation will allow them to generate cost savings by optimizing manufacturing, eliminating redundant overheads and leveraging purchasing volumes.

UPM-Kymmene is one of the most internationally focussed paper companies in the world. Just last year that particular organization formed a joint venture with APRIL, the large Singapore player, to create the biggest alliance for the production of fine papers. It also bought Blandin Paper from Fletcher Challenge to increase its global coverage.

The company is now focussing on being a global producer rather than simply a global seller, and — no surprises here it's narrowing its focus on products by spinning off non-core assets.

Consolidation, globalization, specialization. I know I've said those words a lot today, but they're worth remembering. In fact, for the three merged organizations I just discussed — and from what Pat Crowley told us about the successes at AbitibiConsolidated - those words are now a way of life for some of the industry's most successful companies.

For most organizations in general the benefits of consolidation alone are too good to ignore:

- Economies of scale in logistics, marketing, research and administration;

- Streamlined production by managing capacity better;

- Supply chain partnerships with huge savings; and

- Sharing best practices - to name only a few. 
But what about the challenges of consolidation? Given the $\$ 20$ billion global merger between Coopers \& Lybrand and Price Waterhouse, I must know about some of those, right?

You bet I do. We just brought together 145000 people worldwide, so I know about the challenges, and I know about the rewards. But, perhaps most important of all, I've learned some valuable lessons about how to make a merger work and I'm going to share some of them with you today. If my theme of "consolidation, globalization, specialization" catches on in this industry as much as it should, it's only going to be a matter of time before more of our forest companies find themselves in the midst of merger mania.

So how do you make a merger work? I could probably write a book about it, to tell the truth. But today I'm going to limit my advice to a few key pointers.

First of all, you have to begin with a vision. Jim Schiro and Nick Moore, respectively the global CEO and chairman of PricewaterhouseCoopers, are fond of saying that our merger firms started with the two of them - with their ability to get along and share a vision.

If you can't share a vision, forget it. And if you can't get your people excited about that vision, you can forget it again. Because your people are your front line. If they don't understand your vision, if they don't understand what direction you're heading in, you're at risk. No matter how good a leader you are, you simply cannot lead without followers. So make sure your followers are right behind you.

Second, however trite this sounds, don't forget about your customers. The amount of internal energy demanded by a merger is extreme: you have to address benefits, compensation, methodologies, technology, businesses processes and so much more. But if you spend too much time focussing inward instead of focussing on your customers, you'll be dead in the water - and you'll find yourself wondering why you ever chose to merge in the first place.

Look at the internal issues facing Stora-Enso, for example. Even before the organization can address the issues I just mentioned - benefits, compensation, methodologies, etc. the company has to contend with different cultures, different languages and different accounting standards. And you can bet that not one of those internal issues will be resolved over the short term.

The solution? A lean transition team. Dedicate a small number of people to the internal activities critical to consummating the merger - and make sure everybody else continues to focus on customer service.

Third, integrate your business processes as quickly as possible. The sooner you stop acting like two different organizations, the sooner you'll stop being two different organizations.
At PricewaterhouseCoopers, for example, we trained 60000 people worldwide in the single audit methodology we're using to audit all our clients. And we did that within our first two months as a merged firm. It was a monumental undertaking - but absolutely necessary. If you're going to promise to deliver single methodologies to your customers - like we did you had better be prepared to do it... and do it quickly.

Fourth, and most important, remember that after the merger you must be more than the sum of your parts. In this situation - no matter what your accountant tells you - one plus one does not equal two. It should equal three.

The goal of a successful merger is to adopt the best practices of each organization - and in some instances to develop entirely new approaches for an entirely new company. Because that's one of the advantages of merging. If you operate according to the principle that one plus one equals three, a merger gives you the opportunity to re-examine every single thing you do. It gives you the opportunity to build the platform from which you're going to change the competitive landscape. Remember: one plus one does not equal two. One plus one should equal something new.

By consolidating, globalizing and specializing, today's forest industry mergers are indeed changing the competitive landscape. And who better than us to continue changing it? After all, we have a 300 -year tradition in forest behind us - 300 years of change to learn from.

So what will the forest products landscape look like over the next few years? Well, let's take a look into the future. By 2001 the top-performing forest products companies will probably look like this:

- They'll have at least $\$ 10$ billion annual sales, with strong growth potential. Today, only two Canadian companies can boast sales of $\$ 5$ billion.

- They'll be organized around core competencies.

- They'll be profitable, with strong shareholder value.

- They will have a clear fibre supply strategy.

- A very strong customer focus, and

- World-class logistics, including global supply chain integration.

In other words, they will have reaped the benefits of consolidation, globalization, specialization - and the result will be fewer, more significant players.

Will you be one of them?

I hope you will be. And, if I can be as honest in concluding my remarks as I was when I began them, I hope you'll take PricewaterhouseCoopers along for the ride. It's bound to be an exciting one. 